\title{
Impact of different lignocellulose substrates on growth and yield of oyster mushroom (Pleurotus ostreatus)
}

\author{
Abid Hussain Abid ${ }^{1}$, Abdul Hamid ${ }^{1}$, Raja Mohib Muazzam Naz ${ }^{*}$, Syed \\ Zulfiqar Ali Shah ${ }^{1}$, Salma Anjum ${ }^{1}$, Muhammad Tariq Khan ${ }^{2}$ and \\ Muhammad Ilyas ${ }^{3}$ \\ 1. Department of Horticulture, Faculty of Agriculture, University of the Poonch, Rawalakot, Azad Jammu \& \\ Kashmir-Pakistan \\ 2. Department of Plant Pathology, Faculty of Agriculture, University of the Poonch, Rawalakot, Azad Jammu \& \\ Kashmir-Pakistan \\ 3. Department of Plant Breeding and Molecular Genetics, Faculty of Agriculture, University of the Poonch, \\ Rawalakot, Azad Jammu \& Kashmir-Pakistan \\ *Corresponding author's email: mohibhortian@gmail.com \\ Citation \\ Abid Hussain Abid, Abdul Hamid, Raja Mohib Muazzam Naz, Syed Zulfiqar Ali Shah, Salma Anjum, Muhammad \\ Tariq Khan and Muhammad Ilyas. Impact of different lignocellulose substrates on growth and yield of oyster \\ mushroom (Pleurotus ostreatus). Pure and Applied Biology. Vol. 9, Issue 1, pp768-775. \\ http://dx.doi.org/10.19045/bspab.2020.90083
}

Received: 18/09/2019

Revised: 01/12/2019

Accepted: 09/12/2019

Online First: 24/12/2019

\section{Abstract}

Mushrooms are increasingly becoming an important component of diets worldwide and it is of paramount importance to choose appropriate substrates in a given place to grow them. The experiment was conducted at University of the Poonch Rawalakot-Pakistan. The present study was focused to evaluate the growth and yield of Pleurotus ostreatus cultivar on different lignocellulose substrates. Four types of lignocellulose substrate namely (paddy straw, wheat straw, sawdust of Chir and sawdust of Kail and their combinations) were arranged in a completely randomized design (CRD) with three replications. The data was recorded on days to completion of spawn running, days for appearance of pinheads, number of pinheads, no. of fruiting bodies, days to maturation, mushroom yield (g), biological efficiency (\%) and protein content (\%). Optimal temperature $\left(25^{\circ} \mathrm{C}\right)$ and high relative humidity were provided for oyster growth. No. of pinheads (21.33), no. of fruiting bodies (15.33), days to maturation (11.66), mushroom yield 232g and biological efficiency (BE) 38.66 (\%) were achieved on wheat straw. Therefore, wheat straw is recommended for Pleurotus ostreatus cultivation. As conclusion, this study was put the baseline information to cultivate mushrooms other edible mushrooms on this substrate used for cultivation. Keywords: Fruit body; Lignocellulose; Mushroom; Pleurotus ostreatus; Substrate

\section{Introduction}

Oyster mushroom (Pleurotus ostreatus) belongs to family Pleurotaceae, genus Pleurotus under the order Agaricales, and the class Basidiomycetes. In world production oyster mushroom has occurred third position [1] and growing throughout the world, particularly in Southeast Asia, India, Europe and Africa [2]. These mushrooms make food protein from waste and it needs short growing 
period as compared with other type and cheap to grow for commercial purpose [3]. Waste produce from agricultural operation and from industries can be used for mushroom growing [4]. High productivity, good nutritional and sensory characteristics of oyster mushroom highlights its important as useful food [5]. Many degenerative diseases tumor growth and atherosclerosis can be reduced by use of oyster mushroom in daily diet [6]. Carbohydrates contents present that give resistant against human immune deficiency (HIV) virus [7]. Many bio-active elements present in mushroom have great resistance against bacteria, fungi and virus and also for nematodes and insects [8].

Oyster mushroom contains $19-35 \%$ proteins on dry weight as compared to $7.3 \%$ in rice, $13.2 \%$ in wheat and $25.2 \%$ in milk. The chemical composition of the fresh fruiting bodies of oyster mushroom indicates a large quantity of moisture $(90.8 \%)$, whereas fresh as well as dry oyster mushrooms are rich in proteins $(30.4 \%)$, fat $(2.2 \%)$, carbohydrates $(57.6 \%)$, fiber $(8.7 \%)$ and ash $(9.8 \%)$ with $345 \mathrm{Kcal}$ energy value on $100 \mathrm{~g}$ dry weight basis. It is a source of multivitamins like thiamin $(4.8 \mathrm{mg})$, riboflavin $(4.7 \mathrm{mg})$ and niacin (108.7 mg), B1, B2 and C and minerals like $\mathrm{Ca}(98 \mathrm{mg}), \mathrm{P}(476 \mathrm{mg}), \mathrm{Fe}(8.5 \mathrm{mg})$ and $\mathrm{Na}(61 \mathrm{mg}), \mathrm{K}$ (361 mg), on $100 \mathrm{~g}$ dry weight basis [9]. Today China is a major producer and consumer of oyster mushrooms accounting for about $90 \%$ of the world production [10]. Its present production is approximately 1.5 million tons in the world. Every year 90 tons of mushrooms are exported to Europe from Pakistan [11].

Mushrooms are grown on the organic medium known as substrate. Various lignocellulosic substrates are used for growing of different Pleurotus varieties [12]. Oyster mushroom might be cultivated in various substrates like saw dust, soybean straw, wheat straw and groundnut shells [2], newspaper and tea leaves, cotton waste and paddy straw [13]. However, substrate that contains carbohydrates, nitrogen and lignin can be suitable for better growth of mushroom [14].

For successful mushroom cultivation needs three important factors like seed, growing media and suitable environmental conditions [15]. Different growing media could be suggested for different regions due to feasibility of agri-waste material in that regions [16]. Conversion of fruiting bodies from lignocellulosic material through mushroom growing resulting in profit increase [17]. Supplement of organic and inorganic ingredients are given to growing media enhance and development the yield of mushrooms [18]. Rice waste is mostly used in Asia, as growing media for mushroom cultivation and contain protein and high yield [19]. In Europe wheat residues mostly used as growing media and Southeast Asian countries mostly used sawdust as growing medium for growing mushrooms [2].

Temperature for oyster mushroom cultivation ranges from 20 to $30^{\circ} \mathrm{C}$ and humidity ranges from 55 to 70 percent for duration of seven month per year. In high elevation areas it can be grown in summer season by giving them high humidity. MarchApril and September-October suitable for growing mushroom in higher elevation and October-march for lower elevation [20].

This research was designed to evaluate the oyster mushroom at Rawalakot using different substrates to promote the mushroom cultivation in Azad Kashmir. Mushrooms cultivation has not brought the attention in the public at large scale in Azad Jammu and Kashmir to become an important food item. Primary reason is unavailability of cheap mushrooms spawn, deficiency of information about mushroom cultivation and their nutritional value. Hence, it is the need of hour that there should be commercialization of mushroom cultivation in Azad Kashmir by creating awareness about quality, growing 
technology, economic importance and nutritional value of this crop.

Materials and methods

\section{Geographic position of the study area}

The study area lies between an altitude of 1800-2100 $\mathrm{m}$ above sea level and latitude of $33-36^{\circ}$ in the north-east of Pakistan under the foothills of great Himalayas in Rawalakot district of Poonch Division. The topography of the area is mainly hilly and mountainous with valleys and stretches of plains. The climate is moist subtropical to cold temperate with an average rain fall varying from 800 to $1600 \mathrm{~mm}$.

\section{Collection Pleurotus ostreatus spawn}

Spawn can be regarded as the seed of a mushroom. Spawn is the starting material for mushroom production. Pleurotus ostreatus spawn was obtained from the Department of Horticulture, The University of Agriculture Faisalabad (UAF) Pakistan.

\section{Substrate preparation}

Substrates for growing Pleurotus ostreatus mushroom were made according to Hadar [21] with some modifications. Different substrates have been used by different researchers for the production of various mushroom species. However, most of the substrates are usually of organic origin. In this study, four basal substrates and their combinations for oyster mushroom production were used (Table1). The substrates were soaked in water for one day and located in concrete floor for removing unwanted moisture content from growing material and brought to desire level of 65$75 \%$. Before filling sterilization of these growing media was done by placing them in sunlight and covered by polypropylene bags. Each growing media was filled in bags and tight with plastic rings. The bags were filled in such as way so as to fill 3/4th of bag only in order to leave some space for air and tying up. Substrates were autoclaved with 15-20 lbs pressure at $121^{\circ} \mathrm{C}$ for 15 minutes and left overnight for cooling. The bags were opened inside a laminar flow unit and for $600 \mathrm{~g}$ dry weight of each substrate, $6 \mathrm{~g}$ spawn was used. The bags were then shifted to the mushroom room for running of spawn.

\section{Growth room conditions}

Inoculated bags were then transferred to the growth room. Bags were incubated at $25^{\circ} \mathrm{C}$ under dark conditions till complete spawn running. Running of spawn and formation of fruits were two critical stages throughout mushroom growing period and optimum humidity and temperature for these stages were most important. The growth temperature and moisture were maintained by using heaters and sprinklers at $25^{\circ} \mathrm{C}$ with $50-65 \%$ relative humidity, running of spawn $17-20^{\circ} \mathrm{C}$ for fruit sett. Relative humidity 80 $85 \%$ was maintained for fruit formation, if moisture was found less then amount was achieved by giving water two times per day. For spawn running bags were frequently observed and fungal/bacterial contamination. Proper ventilation was provided in mushroom room because during formation of mushroom fruits need oxygen and also cuts were made in bags for conversation of gasses. After spawn running completion, light is provided for fruiting bodies initiation.

\section{Growth parameters}

The data was recorded on days to completion of spawn running, days for appearance of pinheads, number of pinheads, number of fruiting bodies, days to maturation, mushroom yield $(\mathrm{g})$, biological efficiency $(\%)$ and protein content (\%).

\section{Statistical analysis}

Obtained data was statistically analysed using ANOVA with the help of Statistix 8.1 software; Tukey HSD value was used to equate the variance between means [22].

\section{Results and discussion}

\section{Days to completion of spawn running}

There were significant variations in the days taken for completion of spawn run of different lignocellulose substrates (Table 2). Results regarding the days for completion of 
spawn running showed that best results were obtained from $\mathrm{T}_{2}$ (100\% wheat straw) 19.50 days. Minimum number of days for spawn running was followed by $\mathrm{T}_{5}(50 \%$ paddy straw $+50 \%$ wheat straw) which took number of days (23.50) for spawn running. However, $\mathrm{T}_{4}(100 \%$ sawdust of Kail Pinus wallichiana) took maximum number of days (41.66). Results regarding days for completion of spawn running showed that $T_{2}$ substrate performed best for completion of spawn running and took minimum period for this important aspect of crop growth. Results of present study are in accordance with the findings of Shah et al. [11] who reported that the spawn running completion of Pleurotus ostreatus was taken minimum number of days in wheat straw. Differences in spawn running may be due to the size of the grains. Smaller grains have a more inoculation points per $\mathrm{kg}$ as compared to larger grains [23].

\section{Days for appearance of pinheads}

Appearance of pinheads is very first stage of mushroom growth. The appearance has tiny mushroom growing out of the substrates. Data revealed that there was highly significance difference among treatments (Table 2). Results regarding the days for appearance of pinheads showed that best results were obtained with $\mathrm{T}_{2}(100 \%$ wheat straw) which took (16.50) days. Minimum number of days for appearance of pinheads was followed by $\mathrm{T}_{5}(50 \%$ paddy straw $+50 \%$ wheat straw) which took number of days (17.50). However, $\mathrm{T}_{4}$ (100\% saw dust of Kail Pinus wallichiana) took maximum number of days (26.00). Results regarding the days for appearance of pinheads performed best with $\mathrm{T}_{2}$ (100\% wheat straw). This may be since substrates having high quality cellulose and lignin content took longer to start pinning. Our results were in accordance with the findings of Shah et al. [11] and Ahmad [24] who reported that the appearance of pinheads of Pleurotus ostreatus was take a minimum number of days in wheat straw substrates.

\section{No. of pinheads}

The data regarding the number of pinheads were subjected to statistical analysis and the results obtained from analysis of variance are shown in (Table 2). Data revealed that there was highly significance difference among treatments for number of pinheads. Results regarding the number of pinheads showed that best results were obtained from $\mathrm{T}_{2}(100 \%$ wheat straw) which took (21.33) followed by $\mathrm{T}_{5}(50 \%$ paddy straw $+50 \%$ wheat straw $)$ which took (19.50). The difference for this parameter was highly significant. Findings of present research were similar with the findings of Ogundele et al. [25] observed that maximum number of pinheads in pure substrate. However, Buah et al. [26] reported pinhead formation of $P$. ostreatus on different substrates after 21-23 days.

\section{No. of fruiting bodies}

The data regarding the number of fruiting bodies were subjected to statistical analysis and the results obtained from analysis of variance (ANOVA) are shown in (Table 2). Data revealed that there was highly significance difference among treatments. Best results were obtained from $\mathrm{T}_{2}(100 \%$ wheat straw) which took (15.33) (Figure 1). While minimum number (3.16) was obtained by $\mathrm{T}_{4} \quad(100 \%$ sawdust of Kail (Pinus wallichiana). Our findings are in contradiction with the findings of Girmy et al. [27] observed that minimum number of fruiting bodies with wheat straw. This could be due to the day and night temperature difference. This contradiction may be due to different climatic condition of that area.

\section{Days to maturation}

The data regarding the number of days for fruiting bodies maturation were subjected to statistical analysis and the results obtained from analysis of variance (ANOVA) are shown in (Table 2). Data revealed that there was highly significance difference among 
treatments. Best results were obtained from $\mathrm{T}_{4}$ (100\% sawdust of Kail Pinus wallichiana) which took (2.16). Results regarding days for maturity $\mathrm{T}_{4}$ performed best for days to maturity. This may be due to the growing conditions and physiological factors like light, temperature and humidity for mushroom growing. Our results were similar with the results of Buah et al. [26] who observed that minimum day in maturity in fruiting bodies in Kail Pinus wallichiana sawdust.

\section{Mushroom yield (g)}

The data regarding the total mushroom yield were subjected to statistical analysis and the results obtained from analysis of variance (ANOVA) are shown in (Table 2). Data revealed that there was highly significance difference among treatments. Results regarding the total mushroom yield showed that best results were obtained from $\mathrm{T}_{2}(100 \%$ wheat straw) which took maximum mushroom yield (232g). While minimum $(22.17 \mathrm{~g})$ was obtained with $\mathrm{T}_{4} \quad(100 \%$ sawdust of Kail (Pinus wallichiana). The difference for this parameter was highly significant. This could be due to the day and night temperature. This could be due to the main function of wheat straw is to provide a reservoir of cellulose, hemicellulose and lignin, which is utilized during the growth of mycelium running and during fruit body formation. A variable quantity of nitrogen is also provided by wheat straw. Our results were similar with the results of Assan and Mpofu [28] who observed that maximum yield in wheat straw.

\section{Biological efficiency (\%)}

Biological efficiency is the ratio of the weight of the fresh fruiting bodies ( $\mathrm{g}$ ) per dry weight of substrates $(\mathrm{g})$. It expressed as a percentage. The data regarding the biological efficiency was subjected to statistical analysis and the results obtained from analysis of variance (ANOVA) are shown in (Table 2). Data revealed that there was highly significance difference among treatments. Maximum biological efficiency $(38.66 \%)$ was obtained from $\mathrm{T}_{2}\left(100 \%\right.$ wheat straw) followed by $\mathrm{T}_{5}$ $(50 \%$ paddy straw $+50 \%$ wheat straw $)$ which took (35.27). However, $\mathrm{T}_{4}$ (sawdust of Kail Pinus wallichiana) took minimum $(2.76 \%)$ biological efficiency. The differences in yield and biological efficiency observed between treatments are not surprising because the chemical composition of the substrate is different. Our results were enlaced with Garo and Girma [29] who also studied maximum biological efficiency in wheat straw substrates.

\section{Protein content (\%)}

The data regarding the total protein content were subjected to statistical analysis and the results obtained from analysis of variance (ANOVA) are shown in (Table 2). Data revealed that there was highly significance difference among treatments. Best results were obtained from $\mathrm{T}_{6}(50 \%$ paddy straw + $50 \%$ saw dust of Chir Pinus roxburgii) which took maximum protein content $(22.34 \%)$ and followed by $\mathrm{T}_{7}(50 \%$ paddy straw $+50 \%$ sawdust of Kail Pinus wallichiana) which took $(20.73 \%)$. However, $\mathrm{T}_{10}(50 \%$ sawdust of Chir Pinus roxburgii $+50 \%$ sawdust of Kail Pinus wallichiana) took minimum $(10.87 \%)$ protein content. The difference for this parameter was highly significant. The increase in protein content high due to mixture of substrates use. Findings of our study were related with Ogundele et al. [25] who reported that protein content of oyster mushroom Pleurotus ostreatus high in mix substrates. 
Table 1. The composition of different substrates used for oyster mushroom production

\begin{tabular}{|c|c|}
\hline Treatments & Substrates \\
\hline $\mathbf{T}_{\mathbf{1}}$ & 100\% paddy straw \\
\hline $\mathbf{T}_{\mathbf{2}}$ & 100\% wheat straw \\
\hline $\mathbf{T}_{\mathbf{3}}$ & $100 \%$ sawdust of Chir (Pinus roxburghii) \\
\hline $\mathbf{T}_{\mathbf{4}}$ & 100\% sawdust of Kail (Pinus wallichiana) \\
\hline $\mathbf{T}_{\mathbf{5}}$ & $50 \%$ paddy straw $+50 \%$ wheat straw \\
\hline $\mathbf{T}_{\mathbf{6}}$ & $50 \%$ paddy straw $+50 \%$ sawdust of Chir (Pinus roxburghii) \\
\hline $\mathbf{T}_{\mathbf{7}}$ & $50 \%$ paddy straw $+50 \%$ sawdust of Kail (Pinus wallichiana) \\
\hline $\mathbf{T}_{\mathbf{8}}$ & $50 \%$ wheat straw $+50 \%$ sawdust of Chir (Pinus roxburghii) \\
\hline $\mathbf{T}_{\mathbf{9}}$ & $50 \%$ wheat straw $+50 \%$ sawdust of Kail (Pinus wallichiana) \\
\hline $\mathbf{T}_{\mathbf{1 0}}$ & $50 \%$ sawdust of Chir (Pinus roxburghii) + 50\% sawdust of Kail (Pinus wallichiana) \\
\hline
\end{tabular}

Table 2. Effect of different substrates on various attributes of oyster mushroom $(\dagger)$

\begin{tabular}{|c|c|c|c|c|c|c|c|c|}
\hline $\begin{array}{c}\text { Treatment } \\
\text { s }\end{array}$ & $\begin{array}{c}\text { Days to } \\
\text { completion } \\
\text { of spawn } \\
\text { running }\end{array}$ & $\begin{array}{c}\text { Days for } \\
\text { appearanc } \\
\text { e of } \\
\text { pinheads }\end{array}$ & $\begin{array}{c}\text { No. of } \\
\text { pinheads }\end{array}$ & $\begin{array}{l}\text { No. of } \\
\text { fruiting } \\
\text { bodies }\end{array}$ & $\begin{array}{c}\text { Days to } \\
\text { maturatio } \\
n\end{array}$ & $\begin{array}{c}\text { Mushroom } \\
\text { yield (g) }\end{array}$ & $\begin{array}{c}\text { Biological } \\
\text { efficiency } \\
(\%)\end{array}$ & $\begin{array}{c}\text { Protein } \\
\text { content }(\%)\end{array}$ \\
\hline $\mathbf{T}_{1}$ & $25.83 \mathrm{E}$ & $18.66 \mathrm{G}$ & $17.50 \mathrm{C}$ & $12.50 \mathrm{~B}$ & $10.00 \mathrm{~B}$ & $184.50 \mathrm{C}$ & $30.74 \mathrm{C}$ & $13.030 \mathrm{H}$ \\
\hline $\mathbf{T}_{2}$ & $19.50 \mathrm{G}$ & $16.50 \mathrm{H}$ & $21.33 \mathrm{~A}$ & $15.33 \mathrm{~A}$ & $11.66 \mathrm{~A}$ & $232.00 \mathrm{~A}$ & $38.66 \mathrm{~A}$ & $15.518 \mathrm{G}$ \\
\hline $\mathbf{T}_{3}$ & $39.66 \mathrm{~A}$ & $24.66 \mathrm{~B}$ & $06.83 \mathrm{H}$ & $05.16 \mathrm{G}$ & $03.33 \mathrm{~F}$ & $32.50 \mathrm{H}$ & $04.06 \mathrm{H}$ & $16.758 \mathrm{E}$ \\
\hline $\mathbf{T}_{4}$ & $41.66 \mathrm{~A}$ & $26.00 \mathrm{~A}$ & $04.83 \mathrm{I}$ & $03.16 \mathrm{H}$ & $02.16 \mathrm{~F}$ & $22.17 \mathrm{H}$ & $02.76 \mathrm{H}$ & $17.750 \mathrm{D}$ \\
\hline $\mathbf{T}_{5}$ & $23.50 \mathrm{G}$ & $17.50 \mathrm{H}$ & $19.50 \mathrm{~B}$ & $14.00 \mathrm{~A}$ & $12.66 \mathrm{~A}$ & $211.67 \mathrm{~B}$ & $35.27 \mathrm{~B}$ & $19.00 \mathrm{C}$ \\
\hline $\mathbf{T}_{6}$ & $27.83 \mathrm{DE}$ & 19.66 FG & $\begin{array}{c}16.00 \\
\mathrm{CD}\end{array}$ & $\begin{array}{c}11.33 \\
\mathrm{BC} \\
\end{array}$ & 09.16 B & $165.00 \mathrm{D}$ & $23.56 \mathrm{D}$ & $22.34 \mathrm{~A}$ \\
\hline $\mathbf{T}_{7}$ & $29.83 \mathrm{D}$ & $20.66 \mathrm{EF}$ & $14.66 \mathrm{D}$ & $\begin{array}{c}10.00 \\
\mathrm{CD}\end{array}$ & $07.66 \mathrm{C}$ & $132.00 \mathrm{E}$ & $18.85 \mathrm{E}$ & $20.73 \mathrm{~B}$ \\
\hline $\mathbf{T}_{8}$ & $32.33 \mathrm{C}$ & $21.66 \mathrm{DE}$ & $12.33 \mathrm{E}$ & $\begin{array}{c}08.83 \\
\mathrm{DE}\end{array}$ & $06.83 \mathrm{CD}$ & $120.17 \mathrm{E}$ & $17.16 \mathrm{E}$ & $16.06 \mathrm{~F}$ \\
\hline $\mathbf{T}_{9}$ & $34.33 \mathrm{C}$ & $22.66 \mathrm{CD}$ & $10.50 \mathrm{~F}$ & $\begin{array}{c}07.50 \\
\text { EF }\end{array}$ & $05.83 \mathrm{DE}$ & $83.83 \mathrm{~F}$ & $11.97 \mathrm{~F}$ & $12.79 \mathrm{H}$ \\
\hline $\mathbf{T}_{10}$ & $37.00 \mathrm{~B}$ & $23.66 \mathrm{BC}$ & $08.50 \mathrm{G}$ & $\begin{array}{c}06.33 \\
\text { FG } \\
\end{array}$ & $04.83 \mathrm{E}$ & $50.83 \mathrm{G}$ & $06.35 \mathrm{G}$ & $10.87 \mathrm{I}$ \\
\hline HSD & 2.08 & 1.12 & 1.50 & 1.34 & 1.27 & 13.23 & 2.00 & 0.78 \\
\hline
\end{tabular}

${ }^{\dagger}$ Means with different letters in column are significantly different at $P<0.05$ using HSD.

Each value is the mean of three replicates 

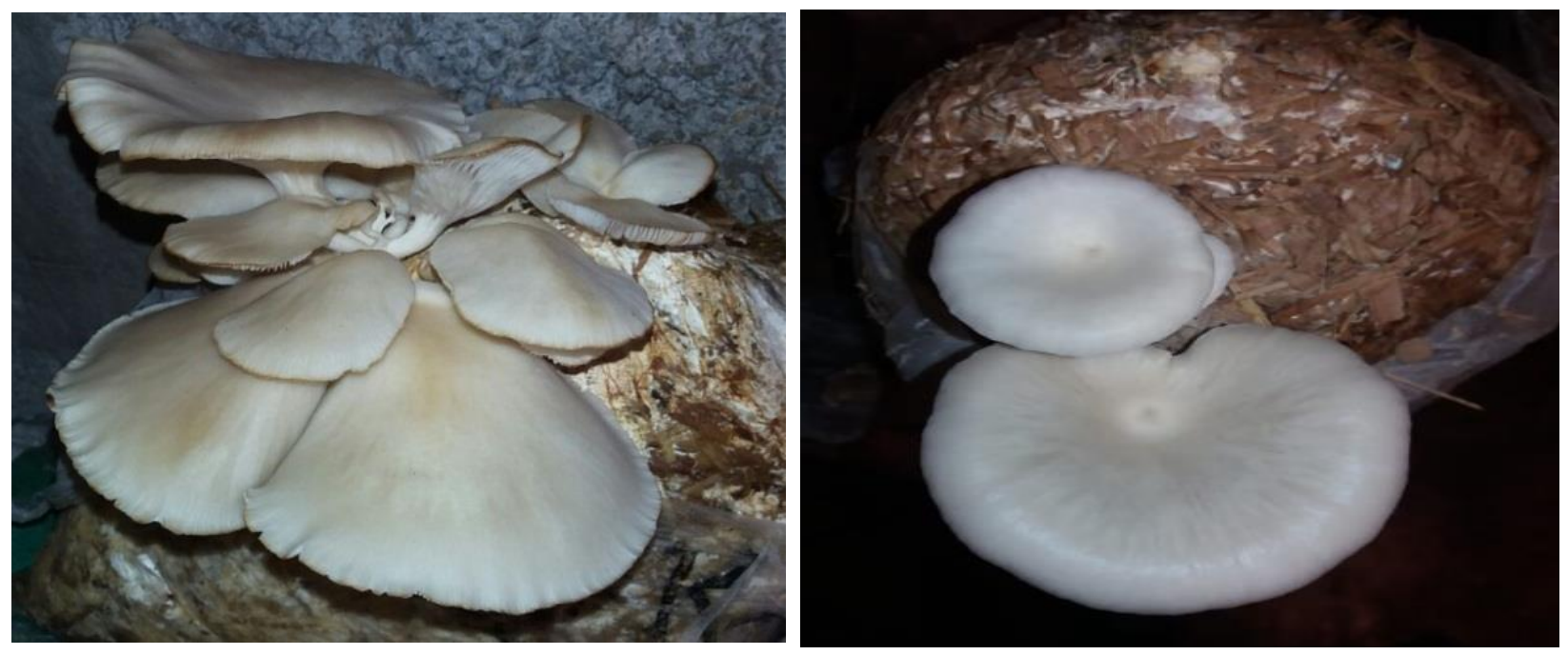

Figure 1. Fruiting bodies of Oyster mushroom developed on wheat straw at first flush

\section{Conclusion and recommendation}

It is concluded from the experiment that wheat straw is the best lignocellulosic substrate for the growth of oyster mushroom under rain fed climatic conditions. Further research could be done on paddy straw substrate to get its benefits for high yield of crop to become economical for local formers of Azad Jammu and Kashmir as it is a very cheap and easily available.

\section{Authors' contributions}

Conceived and designed the experiments: A Hamid \& SZA Shah, Performed the experiments: AH Abid, \& S Anjum, Analyzed the data: RMM Naz \& MT Khan, Contributed reagents/ materials/ analysis tools: A Hamid, SZA Shah, MT Khan \& M Ilyas, Wrote the paper: RMM Naz, S Anjum, AH Abid \& M Ilyas.

\section{References}

1. Gyorfi J \& Hajdu CS (2007). Casingmaterial experiments with Pleurotus eryngi. Inter J Hortic Sci 13: 33-36.

2. Mane VP, Patil SS, Syed AA \& Baig MMV (2007). Bioconversion of low quality lignocellulosic agricultural waste into edible protein by Pleurotus sajor-caju (Fr.) Singer. J Zhejiang Uni Sci 8: 745-751.

3. Kausar T (1998). Cultivation of mushrooms using crop residues as substrate. Ph.D Thesis. Department of Botany. University of Punjab Lahore, Pakistan.
4. Hayes S (1978) Ecology resources and mushroom cultivation. Mushroom J 84: 515525.

5. Eswaran A \& Ramabadran R (2000). Studies on some physiological, cultural and postharvest aspects of oyster mushroom (Pleurotus ostreatus). Trop Agri Res J 12: 360-374.

6. Bahl NITA (1983). Medicinal value of edible fungi. In Proceeding of the international conference on science and cultivation technology of edible fungi. Indian Mushroom Sci II: 203-209.

7. Nanba H (1993). Shiitake mushroom the king mushroom. Mushroom News 41: 22-25.

8. Zhang L, Fan C, Liu S, Zang Z, Jiao L \& Zhang L (2011). Chemical composition and antitumor activity of polysaccharide from Inonotus obliquus. J Med Plants Res 5: 1251-1260.

9. Pandey A, Soccol CR, Nigam P, Brand D, Mohan R \& Roussos S (2000). Biotechnological potential of coffee pulp and coffee husk for bioprocesses. Bioch Eng J 6:153-162.

10. Mohamed MF, Refaei EF, Abdalla MM \& Abdelgalil SH (2016). Fruiting bodies yield of oyster mushroom (Pleurotus columbinus) as affected by different portions of compost in the substrate. Inter J Recycl Org Waste Agric 5: 281-288. 
11. Shah ZA, Ashraf M \& Ishtiaq M (2004). Comparative study on cultivation and yield performance of oyster mushroom (Pleurotus ostreatus) on different substrates (wheat straw, leaves, saw dust). Pak J Nutr 3:158160.

12. Sánchez C (2004). Modern aspects of mushroom culture technology. Appl Microbiol Biotechnol 64: 756-762

13. Ashraf J, Ali MA, Ahmad W, Ayyub CM \& Shafi J (2013). Effect of different substrate supplements on oyster mushroom (Pleurotus spp.) production. Food Sci Tech 1: 44-51.

14. Das N \& Mukherjee M (2007). Cultivation of Pleurotus ostreatus on weed plants. Bioresour Tech 98:2723-2726.

15. Rajapakse JC, Rubasingha P \& Dissanayake NN (2007). The potential of using costeffective compost mixtures for oyster mushroom (Pleurotus spp.) cultivation in Sri Lanka. Trop Agric Res Ext 10: 29-32.

16. Cohen R, Persky L \& Hadar Y (2002). Biotechnological applications and potential of wood-degrading mushrooms of the genus Pleurotus. Appl Microbiol Biotechnol 58: 582-594.

17. Kües U \& Liu Y (2000). Fruiting body production in basidiomycetes. Appl Microbiol Biotechnol 54: 141-152.

18. Chaubey A, Dehariya P \& Vyas D (2010). Solid waste management through oyster mushroom cultivation. Inter J Biozone 2: 369- 372.

19. Thomas GV, Prabhu SR, Reeny MZ \& Bopaiah BM (1998). Evaluation of lignocellulosic biomass from coconut palm as substrate for cultivation of Pleurotus sajor-caju (Fr.) Singer. World J Microbiol Biotech 14: 879-882.

20. Amin SMR, Nirod CS, Moonmoon M, Khandaker J \& Rahman M (2007). Officer's Training Manual. National Mushroom Development and Extension Centre, Savar, Dhaka, Bangladesh, 6: 7-17.
21. Hadar Y, Kerem Z, Gorodecki B \& Ardon O (1992). Utilization of lignocellulosic waste by the edible mushroom, Pleurotus. Biodegradation 3: 189-205.

22. Steel RGD, Torrie JH \& Dickey DA (1997). Principles and procedures of Statistic: a biometrical approach. $3^{\text {rd }}$ Edition. McGrawHill Publishing Co. Boston, Massachusetts, pp 635.

23. Mamiro DP \& Royse DJ (2008). The influence of spawn type and strain on yield, size and mushroom solids content of Agaricus bisporus produced on noncomposted and spent mushroom compost, Bioresour Technol 99: 3205-3212.

24. Ahmad I (1986). Some studies on Oyster mushroom (Pleurotus spp.) on waste material of corn industry. M.Sc thesis. Department of plant Pathology, The University of Agriculture Faisalabad (UAF).

25. Ogundele GF, Abdulazeez RO \& Bamidele OP (2014). Effect of pure and mixed substrate on oyster mushroom (Pleurotus ostreatus) cultivation. J Exp Biol Agri Sci 2: 216-219.

26. Buah JN, Van der Puije GC, Bediako EA, Abole EA \& Showemimo F (2010). The growth and yield performance of oyster mushroom (Pleurotus ostreatus) on different substrates. Biotechnol 9: 338-342.

27. Girmay Z, Gorems W, Birhanu G \& Zewdie $S$ (2016). Growth and yield performance of Pleurotus ostreatus (Jacq. Fr.) Kumm (oyster mushroom) on different substrates. AMB Express 6: 87.

28. Assan N \& Mpofu T (2014). The influence of substrate on mushroom productivity. Sci J Crop Sci 3: 86-91.

29. Garo G \& Girma G (2016). Responses of oyster mushroom (Pleurotus ostreatus) as influenced by substrate difference in Gamo Gofa zone, Southern Ethiopia. IOSR J Agric Vet Sci 9: 63-8. 